\title{
Peramalan Indeks Harga Konsumen (IHK) di Sulawesi Selatan dengan Menggunakan Metode Singular Spectrum Analysis (SSA)
}

\author{
Satriani \\ Universitas Islam Negeri Alauddin Makassar, abidinsatriani@gmail.com \\ Nursalam \\ Universitas Islam Negeri Alauddin Makassar,nursalam_ftk@uin-alauddin.ac.id \\ Risnawati Ibnas \\ Universitas Islam Negeri Alauddin Makassar, risnawati.ibnas@uin-alauddin.ac.id
}

\begin{abstract}
This study discussed about forecasting the Consumer Price Index (CPI) in South Sulawesi. Generally, CPI was used as indicator to measure the level of inflation and deflation of a group of goods and services. CPI forecasting is important because it is an early detection to aware. This study used Singular Spectrum Analysis (SSA) method. SSA is a nonparametric time series analysis technique. The aims of this study to determine the results of forecasting the consumer price index (CPI) in South Sulawesi from January 2020 to December 2020. This study shown the highest CPI was 146,88 in December 2020 and the lowest one was 141,92 in January 2020, the level of forecasting accuracy resulted measured by Mean Absolute Percentage Error (MAPE) criteria was 1.32\%.
\end{abstract}

Keywords: Consumer Price Index (CPI), Singular Spectrum Analysis, Mean Absolute Percentage Error

\section{PENDAHULUAN}

Indeks Harga Konsumen atau yang biasa disebut IHK berperan penting sebagai dasar perhitungan inflasi suatu wilayah. Perkembangan perekonomian di Sulawesi Selatan pada kurun waktu tertentu mengalami perubahan. Perubahan tersebut dipengaruhi oleh permintaan barang dan jasa Perubahan tersebut terjadi karena meningkatnya permintaan jumlah barang dan jasa yang diminati oleh rumah tangga pada setiap tahunnya. Rata-rata perubahan terhadap harga barang dan jasa dapat diketahui dari perhitungan Indeks Harga Konsumen (IHK). IHK merupakan suatu indikator berupa nilai untuk mengetahui rata-rata perubahan harga dari suatu paket barang dan jasa yang dikonsumsi oleh rumah tangga pada kurun waktu tertentu. Perubahan IHK dari waktu ke waktu menggambarkan deflasi maupun inflasi dari suatu paket barang dan jasa pada umumnya.

Badan Pusat Statistik (BPS) setiap bulannya secara rutin menghitung serta melaporkan perkembangan IHK yang dihitung berdasarkan Survey Biaya Hidup (SBH) di suatu daerah perkotaan atau kabupaten yang dilakukan secara bertahap[1].

Data IHK ini merupakan salah satu yang termasuk data deret waktu (time series) yang dianalisis menggunakan metode peramalan. Peramalan (forecasting) dalam IHK penting dilakukan karena untuk mengetahui perkembangan IHK disuatu wilayah dalam kurun waktu tertentu. Peramalan (forecasting) merupakan salah satu metode dalam ilmu statistik untuk melakukan peramalan keadaan dimasa mendatang, dengan berbagai model yang dapat digunakan salah satunya Model Singular Spectrum Analysis (SSA).

Metode Singular Spectrum Analysis (SSA) merupakan suatu model peramalan yang berkembang saat ini. Hassani (2007), dalam penelitiannya membandingkan metode SSA, SARIMA, ARAR, dan Seational HoltWinter dengan melakukan peramalan pada kasus kematian yang disebabkan kecelakaan di USA tahun 1973. Dengan hasil penelitian bahwa metode yang paling baik dengan menggunakan metode SSA untuk meramalkan kasus tersebut[2]. Penelitian yang dilakukan oleh Myung (2009), dengan hasilnya bahwa metode SSA merupakan metode yang baik digunakan dalam merekonstruksi pola trend dan beberapa komponen lain dengan struktur yang lebih sederhana[3]. Lubis (2019), yang meramalkan data IHK dengan 
membandingkan metode SSA dan SARIMA dan hasilnya menunjukkan bahwa metode SSA menunjukkan peningkatan nilai IHK yang cukup tinggi atau terjadi inflasi yang cukup tinggi[4].

Dari beberapa hasil penelitian diatas menunjukkan bahwa Metode SSA memiliki beberapa keunggulan dibandingkan dengan model time series lainnya. Keunggulan dari metode SSA adalah merupakan suatu metode dengan pendekatan non-parametrik sehingga lebih fleksibel dalam penggunaannya. Selain itu, metode SSA tidak mengandung asumsi-asumsi parametrik sehingga dengan menggunakan metode SSA dapat memberikan hasil peramalan yang akurat.

Metode SSA merupakan metode yang akan digunakan pada penelitian ini, karena melihat dari beberapa keunggulan metode SSA seperti yang disebutkan sebelumnya. Sehingga, Penulis tertarik untuk melakukan penelitian dengan judul "Peramalan Indeks Harga Konsumen (IHK) di Sulawesi Selatan Menggunakan Metode Singular Spectrum Analysis (SSA)".

\section{TINJAUAN PUSTAKA SINGULAR SPECTRUM ANALYSIS (SSA)}

Singular Spectrum Analysis (SSA) adalah metode deret waktu (time series) yang cukup powerfull digunakan untuk melakukan peramalan. SSA juga merupakan suatu teknik nonparametrik yang digunakan untuk mengamati suatu data deret wakttu yang tidak linier, tidak stasioner, dan memiliki sifat berubah-ubah setiap saat ataupun sementara[5].

Menurut Golyandina, SSA adalah suatu metode yang sangat berguna untuk memecahkan beberapa masalah seperti menemukan trend dari resolusi berbeda, smoothing, ekstraksi komponen musiman, ekstraksi simultan untuk siklus dengan periode kecil dan besar, ektraksi periodeitas dengan amplitude yang bervariasi, ekstraksi simultan untuk trend an perioditas yang kompleks, dan mendeteksi change-point [6].
TAHAPAN

MENGGUNAKAN

PERAMALAN

METODE

SINGULAR SPECTRUM ANALYSIS (SSA)

\section{Dekomposisi}

Dekomposisi adalah tahapan awal pada metode SSA yang melibatkan komponen trend, musiman, siklis dan error pada suatu peramalan. Dekomposisi terdiri dari dua tahapan yaitu embedding dan Singular Value Decomposition (SVD).

\section{Embedding}

Embedding adalah tahapan data deret waktu awal diubah menjadi matriks trajectory yang memiliki dimensi $L \quad x \quad K$, dimana $L$ merupakan window length yang menjadi baris matriks, sedangkan $K=N-L+1$ yang menjadi kolom matriks. Rentang pemilihan nilai $L$ adalah $2<L<\frac{N}{2}$, serta asumsi bahwa data deret waktu sepanjang periode $N$ tidak mengandung data hilang (missing data), serta $X=\left\{x_{i}\right\} ; i=1,2, \ldots, N[7]$.

Matriks trajectory $\left(T_{x}\right)$ yang terbentuk merupakan matriks Hankel. Matriks Hankel adalah matriks yang semua elemen di sepanjang diagonal $i+j$ konstan. Matiks trajectory dapat ditulis sebagai berikut:

$\mathrm{T}_{\mathrm{x}}=\left(x_{\mathrm{ij}}\right)_{\mathrm{i}, \mathrm{j}=1}^{\mathrm{L}, \mathrm{K}}=$
$\left[\begin{array}{cccc}x_{1} & x_{2} & \ldots & x_{K} \\ x_{2} & x_{3} & \ldots & x_{K+1} \\ \vdots & \vdots & \ddots & \vdots \\ x_{L} & x_{L+1} & \ldots & x_{N}\end{array}\right](2.1)$

\section{Dekomposisi Nilai Singular (SVD)}

Singular Value Decomposition atau Dekomposisi Nilai Singular bertujuan untuk memperoleh pemisahan komponen dalam dekomposisi dari data deret waktu. SVD dimulai dengan menentukan nilai eigenvalue $\left(\lambda_{1}, \lambda_{2}, \ldots, \lambda_{L}\right)$ dari matriks $S=T_{x} T_{x}{ }^{T}$ dimana $\lambda_{1} \geq \cdots \geq \lambda_{L}>0$, serta eigenvector $\left(U_{1}, U_{2}, \ldots, U_{L}\right)$ dari matriks $\mathrm{S}$ tersebut. Singular Value Decomposition pada Matriks trajectory $T_{x}$ akan menghasilkan: $T_{x i}=$ $U_{i} D_{i} V_{i}^{\prime}$

Dimana:

$U_{i}$ : matriks orthogonal $K x L$ 
$D_{i}$ : matriks diagonal orde $L$

$V_{i}=\frac{X^{T} U_{i}}{\sqrt{\lambda_{i}}}$ : matriks ortonormal bujursangkar $L x L$

Sehingga menghasilkan:

$T_{x i}=\sum_{i=1}^{d} \sqrt{\lambda_{i}} U_{i} V_{i}^{T}$

Dengan $i=1,2, \ldots, d$ dan $d=\max \{\mathrm{i}\} ; \lambda_{i}>0$.

Ketiga komponen dalam matriks $T_{x i}$ yaitu singular value $\left(\sqrt{\lambda_{i}}\right)$, eigenvector $\left(U_{i}\right)$, dan principal component $\left(V_{i}\right)$ disebut eigentriple ke- $i$ dari SVD. Selanjutnya Singular Value Decomposition untuk trajectory matrix $\mathrm{T}_{\mathrm{xi}}$ dapat dituliskan sebagai berikut[8]:

$$
\mathrm{T}_{\mathrm{xi}}=T_{x 1}+T_{x 2}+\ldots+T_{x d}
$$

\section{Rekonstruksi}

Rekonstruksi adalah tahapan selanjutnya dimana data direkonstruksi menjadi data deret waktu yang baru berdasarkan nilai-nilai yang diperoleh pada tahap sebelumnya melalui proses grouping dan diagonal averaging[9].

\section{Grouping}

Grouping adalah tahapan pemisahan komponen-komponen aditif seperti trend, seasonal, dan noise yang terdapat pada data deret waktu. Proses grouping dilakukan dengan cara mengelompokkan set-set indeks $\{1,2, \ldots, d\}$ menjadi $m$ subset yang dapat dilambangkan dengan $I=I_{1}, I_{2}, \ldots, I_{m}$ yang selanjutnya membentuk matriks yang didasarkan pada Singular Value Decomposition untuk trajectory matrix $T_{x i}$ sebagai berikut:

$T_{l x}=T_{l 1}+T_{l 2}+\cdots+T_{l m}$

Tahapan untuk melihat set $I=I_{1}, I_{2}, \ldots, I_{m}$ disebut dengan eigentriple grouping.

\section{Diagonal Averaging}

Diagonal averaging adalah tahapan terakhir pada Singular Spectrum Analysis. Tahapan Diagonal averaging ini adalah tahapan merekonstruksi masing-masing matriks yang terdapat pada matriks $T_{l x}$ menjadi data deret waktu yang baru dengan panjang $\mathrm{N}$.

Misalkan matriks $Y=L \times K ; y, 1 \leq i \leq$ $L, 1 \leq j \leq K$. Matriks $Y$ diubah menjadi deret waktu $g_{0}, \ldots, g_{N-1}$ melalui diagonal averaging yaitu: $g_{k}=$
$\left\{\begin{array}{l}\frac{1}{k+1} \sum_{m=1}^{k+1} y_{m, k-m+2}^{*} ; 0 \leq k<L^{*}-1 \\ \frac{1}{L^{*}} \sum_{m=1}^{L^{*}} y_{m, k-m+2}^{*} ; L^{*}-1 \leq k<K^{*} \\ \frac{1}{N-k} \sum_{m=k-K^{*}+2}^{N-K^{*}+1} y ; K^{*} \leq k \leq N\end{array}\right.$

Dengan :

$$
\begin{gathered}
L^{*}=\min (L, K) ; K^{*}=\max (L, K) \\
N=L+K-1 \\
y_{i j}{ }^{*}\left\{\begin{array}{c}
y_{i j} ; L<K \\
y_{j i} ; \text { selainnya }
\end{array}\right.
\end{gathered}
$$

Dengan $g_{k}$ merupakan rata-rata dari elemen matriks disepanjang diagonal $i+j=k+2$. Untuk $k=0$ akan dihasilkan bahwa $g_{0}=$ $y_{11}, k=1$ akan dihasilkan bahwa $g_{1}=$ $\frac{\left(y_{12}+y_{21}\right)}{2}$, dan seterusnya[10].

\section{UKURAN AKURASI PERAMALAN}

Akurasi peramalan pada penelitian ini menggunakan nilai Mean Absolute Percentage Error (MAPE). Jika $X_{t}$ adalah data aktual untuk periode ke- $t$ dan $F_{t}$ adalah hasil peramalan untuk periode yang sama, maka MAPE dapat dihitung dengan rumus berikut:

$M A P E=\frac{\sum_{i=1}^{t}\left|\left(\frac{X_{t}-F_{t}}{X_{t}}\right) \times 100 \%\right|}{N}$

dengan

$X_{t}$ : data deret waktu aktual

$F_{t}:$ data hasil peramalan

$N$ :jumlah data

Ketika menganalisis kesalahan suatu metode peramalan yang digunakan, sebaiknya MAPE dihitung karena lebih mudah untuk diinterpretasikan nilainya yang merupakan prensentase dari keseluruhan. Interpretasi nilai MAPE dapat dilihat pada Tabel 2.1 berikut[11]:

Tabel 2.1 Interpretasi Nilai MAPE

\begin{tabular}{cc}
\hline MAPE & Interpretasi \\
\hline$<10$ & Peramalan dengan akurasi tinggi \\
$10-20$ & Peramalan yang baik \\
$20-30$ & Peramalan yang layak \\
$>50$ & Peramalan yang tidak akurat \\
\hline
\end{tabular}

\section{METODOLOGI}

Jenis data yang digunakan pada penelitian ini adalah data sekunder yang bersumber dari publikasian Badan Pusat Statistik (BPS) Provinsi Sulawesi Selatan dengan periode 
data dari bulan Januari 2014 sampai bulan Desember 2019. Variabel respon yang digunakan pada penelitian ini adalah variabel Indeks Harga Konsumen (IHK) di Sulawesi Selatan, data yang dimaksud adalah data angka Indeks Harga Konsumen umum.

\section{PROSEDUR PENELITIAN}

1. Mengambil Data Indeks Harga Konsumen (IHK) di Sulawesi Selatan pada Bulan Januari 2014 sampai Desember 2019.

2. Menyajikan plot data IHK menggunakan Software $R$ programming serta melakukan pemeriksaan terhadap plot data tersebut.

3. Menyajikan hasil tahapan peramalan Indeks Harga Konsumen (IHK) Menggunakan Metode Singular Spectrum Analysis (SSA) yang dilakukan dengan dua tahapan sebagai berikut:

- Tahap Dekomposisi, yaitu melakukan proses Embedding dengan cara:

a) Data IHK diubah menjadi matriks Trajectory $L x K$

b) Rentang pemilihan nilai $L$ (Window Length) yang menjadi baris matriks adalah2 $<L<\frac{N}{2}$, dengan $N$ tidak mengandung data hilang (missing data).

c) Sedangkan pemilihan $K$ yang menjadi kolom matriks adalah $K=N-L+1$.

- Melakukan proses Singular Value Decomposition (SVD) dengan cara:

a) Menentukan nilai Singular value $\left(\lambda_{1}, \lambda_{2}, \ldots, \lambda_{L}\right)$ dari matriks $S=T_{x} T_{x}{ }^{T}$ dengan menggunakan Software $R$ programming.

b) Menentukan nilai eigenvector $\left(U_{1}, U_{2}, \ldots, U_{L}\right)$ dari matriks $\mathrm{S}$ tersebut dengan menggunakan Software $R$ programming.

c) Menentukan nilai principal component $\left(V_{1}, V_{2}, \ldots, V_{L}\right)$ dari matriks $\mathrm{S}$ tersebut dengan menggunakan Software $R$ programming.

- Tahap rekonstruksi, yaitu melakukan proses Grouping dengan cara:
Proses grouping dilakukan dengan cara mengelompokkan set-set indeks $\{1,2, \ldots, d\}$ menjadi $m$ subset yang dapat dilambangkan dengan $I=$ $I_{1}, I_{2}, \ldots, I_{m}$ yang selanjutnya membentuk matriks yang didasarkan pada Singular Value Decomposition untuk trajectory matrix $T_{x i}$ sebagai berikut:

$$
T_{l x}=T_{l 1}+T_{l 2}+\cdots+T_{l m}
$$

Melakukan proses Diagonal Averaging

yaitu dengan merekonstruksi masingmasing matriks yang terdapat pada matriks $T_{l x}$ menjadi data deret waktu yang baru dengan panjang $\mathrm{N}$.

4. Tahap Peramalan

5. Memeriksa Akurasi Peramalan dengan menggunakan nilai Mean Absolote Perecentage Error (MAPE) yang dihitung dengan rumus berikut:

$$
M A P E=\frac{\sum_{i=1}^{t}\left|\left(\frac{X_{t}-F_{t}}{X_{t}}\right) \times 100 \%\right|}{N}
$$

dengan

$X_{t}$ : data deret waktu aktual

$F_{t}:$ data hasil peramalan

$N$ :jumlah data

\section{PEMBAHASAN}

DATA

Data yang akan dianalisis pada penelitian ini adalah data Indeks Harga Konsumen (IHK) yang diperoleh dari Publikasian Badan Pusat Statistik Provinsi Sulawesi Selatan, dengan periode data Januari Tahun 2014 sampai Desember Tahun 2019.

Tabel 4.1 Data IHK di Sulawesi Selatan.

\begin{tabular}{cc}
\hline Periode & IHK \\
\hline Januari 2014 & 108.81 \\
Februari 2014 & 109.14 \\
Maret 2014 & 109.17 \\
April 2014 & 109.56 \\
Mei 2014 & 109.53 \\
Juni 2014 & 109.71 \\
Juli 2014 & 111.00 \\
Agustus 2014 & 111.44 \\
September 2014 & 111.72 \\
Oktober 2014 & 112.17 \\
November 2014 & 113.75
\end{tabular}




\begin{tabular}{|c|c|}
\hline Desember 2014 & 116.89 \\
\hline Januari 2015 & 116.69 \\
\hline Februari 2015 & 116.37 \\
\hline Maret 2015 & 116.95 \\
\hline April 2015 & 117.33 \\
\hline Mei 2015 & 117.70 \\
\hline Juni 2015 & 118.55 \\
\hline Juli 2015 & 119.97 \\
\hline Agustus 2015 & 120.41 \\
\hline September 2015 & 121.06 \\
\hline Oktober 2015 & 120.96 \\
\hline November 2015 & 121.28 \\
\hline Desember 2015 & 122.13 \\
\hline Januari 2016 & 123.62 \\
\hline Februari 2016 & 123.52 \\
\hline Maret 2016 & 123.62 \\
\hline April 2016 & 123.14 \\
\hline Mei 2016 & 123.10 \\
\hline Juni 2016 & 123.65 \\
\hline Juli 2016 & 124.93 \\
\hline Agustus 2016 & 124.38 \\
\hline September 2016 & 124.78 \\
\hline Oktober 2016 & 124.78 \\
\hline November 2016 & 125.33 \\
\hline Desember 2016 & 125.71 \\
\hline Januari 2017 & 127.12 \\
\hline Februari 2017 & 128.08 \\
\hline Maret 2017 & 127.84 \\
\hline April 2017 & 128.26 \\
\hline Mei 2017 & 127.95 \\
\hline Juni 2017 & 129.20 \\
\hline Juli 2017 & 130.40 \\
\hline Agustus 2017 & 130.07 \\
\hline September 2017 & 129.98 \\
\hline Oktober 2017 & 129.58 \\
\hline November 2017 & 129.94 \\
\hline Desember 2017 & 131.29 \\
\hline Januari 2018 & 132.35 \\
\hline Februari 2018 & 132.66 \\
\hline Maret 2018 & 132.57 \\
\hline April 2018 & 132.81 \\
\hline Mei 2018 & 133.29 \\
\hline Juni 2018 & 134.55 \\
\hline Juli 2018 & 135.30 \\
\hline Agustus 2018 & 135.16 \\
\hline September 2018 & 134.00 \\
\hline Oktober 2018 & 134.36 \\
\hline November 2018 & 134.73 \\
\hline Desember 2018 & 135.89 \\
\hline Januari 2019 & 136.61 \\
\hline Februari 2019 & 136.36 \\
\hline
\end{tabular}

$\begin{array}{cc}\text { Maret 2019 } & 136.65 \\ \text { April 2019 } & 137.23 \\ \text { Mei 2019 } & 138.28 \\ \text { Juni 2019 } & 138.56 \\ \text { Juli 2019 } & 138.50 \\ \text { Agustus 2019 } & 138.99 \\ \text { September 2019 } & 138.78 \\ \text { Oktober 2019 } & 138.88 \\ \text { November 2019 } & 139.03 \\ \text { Desember 2019 } & 139.08 \\ \text { Sumber: Website Badan Pusat Statistik(BPS) } \\ \text { PLOT DATA }\end{array}$

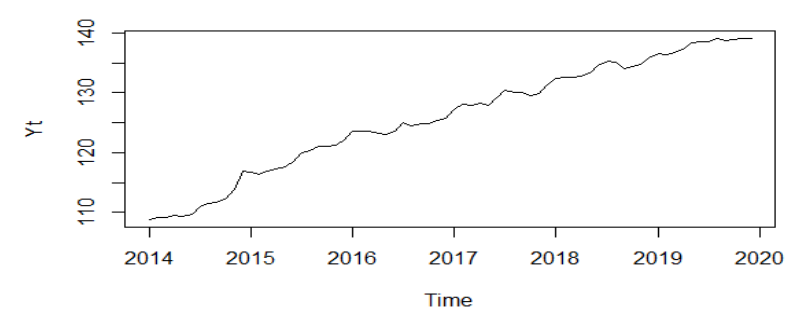

Gambar 4.1 Plot time series dari Data IHK di Sulawesi Selatan

Berdasarkan Gambar 4.1, terlihat pola data Indeks Harga Konsumen (IHK) dari Januari 2014 sampai Desember 2019 (72 bulan) memiliki pola data trend, karena dari plot data menunjukkan kecenderungan data indeks harga konsumen yang terus naik dari tahun ke tahun pada setiap bulannya.

\section{TAHAPAN PERAMALAN INDEKS HARGA KONSUMEN (IHK) MENGGUNAKAN METODE SINGULAR SPECTRUM ANALYSIS (SSA)}

\section{Tahap Dekomposisi Embedding}

Embedding adalah mengubah data deret waktu awal diubah menjadi matriks trajectory. Definisikan suatu deret waktu bernilai real yang memuat IHK periode Januari 2014 sampai Desember 2019, yaitu $F$ $=(108.81,109.14, \ldots, 139.08)$ dengan panjang $N=72$. Window Length $(L)$ adalah parameter tunggal dalam tahap dekomposisi. Pada data IHK nilai parameter Window Length $(L)$ yang diambil adalah $L=36$. Sehingga nilai $K=N-L+1=72-36+$ $1=37$. Dengan demikian matriks lintasan $X$ 
yang terbentuk dari deret $F$ dapat digambarkan sebagai berikut:

$$
\mathrm{T}_{\mathrm{x}}=\left(x_{\mathrm{ij}}\right)_{\mathrm{ij}=1}^{36,37}=\left[\begin{array}{ccccc}
108.81 & 109.14 & 109.17 & \ldots . & 127.12 \\
109.14 & 109.17 & 109.56 & \ldots . & 128.08 \\
109.17 & 109.56 & 109.38 & \ldots . & 127.84 \\
109.56 & 109.38 & 109.71 & . . & 128.26 \\
\vdots & \vdots & \vdots & . & \vdots \\
125.71 & 127.12 & 128.08 & \ldots . & 139.08
\end{array}\right]
$$

\section{Singular Value Decomposition (SVD)}

Langkah awal yang dilakukan pada tahapan SVD adalah membentuk matriks $S=T_{x} T_{x}{ }^{T}$. Langkah selanjutnya adalah memperoleh nilai-nilai eigentriple:

- Singular Value $\sqrt{\lambda_{i}}$

Nilai eigenvalue dan singular value yang diperoleh dengan menggunakan software $R$ Programming adalah sebagai berikut:

Tabel 4.3 Nilai Eigenvalues dan Singular Values

\begin{tabular}{ccc}
\hline No. & Eigenvalues & Singular Values \\
\hline 1 & $4.620416 \mathrm{e}+03$ & 67.9736413 \\
2 & $2.720297 \mathrm{e}+01$ & 5.2156468 \\
3 & $1.116081 \mathrm{e}+01$ & 3.3407798 \\
4 & $1.056381 \mathrm{e}+01$ & 3.2502013 \\
$\vdots$ & $\vdots$ & $\vdots$ \\
36 & $7.347238 \mathrm{e}-02$ & 0.2710579
\end{tabular}

Tabel 4.3 menyajikan nilai eigenvalues dan Singular value. Singular value merupakan hasil akar kuadrat eigenvalue pada matriks $S=T_{x} T_{x}^{T}$. Nilai eigenvalues dan Singular valueakan digunakan untuk mencari nilai principal component.

\section{- Eigenvector $\left(U_{i}\right)$}

Setelah mendapatkan nilai singular value maka seanjutnya tahap perhitungan nilai eigenvector. Dari hasil perhitungan didapatkan nilai eigenvector dengan menggunakan software $R$ Programming sebagai berikut:

Tabel 4.4 Nilai Eigenvectors

\begin{tabular}{cccc}
\hline No. & $U_{1}$ & $\ldots$ & $U_{36}$ \\
\hline 1 & -0.1560087 & $\ldots$ & -0.14804573 \\
2 & -0.1566933 & $\ldots$ & 0.11906211 \\
3 & -0.1573557 & $\ldots$ & -0.16808339 \\
4 & -0.1580305 & $\ldots$ & 0.15504407 \\
5 & -0.1586783 & $\ldots$ & 0.08245036
\end{tabular}
$36 \quad-0.1758447$
$\ldots$
0.14610051

Tabel 4.3 menyajikan nilai dari eigenvector. Nilai eigenvector digunakan untuk mempermudah pemilihan karakteristik dari data.

\section{- Principal Component $\left(V_{i}\right)$}

Nilai principal component dapat dihitung berdasarkar singular value dan eigenvector yang telah diketahui lebih dulu. Nilai principal component dapat dihitung dengan menggunakan persamaan

$$
V_{i}=\frac{X^{T} U_{i}}{\sqrt{\lambda_{i}}}
$$

Dari hasil perhitungan didapatkan nilai principal component dengan menggunakan software $R$ Programming sebagai berikut:

Tabel 4.5 Nilai Principal

\begin{tabular}{cccl}
\hline No. & $V_{1}$ & $\ldots$ & \multicolumn{1}{c}{$V_{36}$} \\
\hline 1 & -0.1535637 & $\ldots$ & -0.0057314199 \\
2 & -0.1542223 & $\ldots$ & 0.1372749035 \\
3 & -0.1549040 & $\ldots$ & -0.1340553058 \\
4 & -0.1555732 & $\ldots$ & 0.1898042782 \\
5 & -0.1562429 & $\ldots$ & -0.1628816114 \\
$\vdots$ & $\vdots$ & $\ddots$ & $\vdots$ \\
37 & -0.1737269 & $\ldots$ & -0.1845626898 \\
\hline
\end{tabular}

Tabel 4.5 menyajikan nilai Principal Component. Nilai principal component yang didapatkan digunakan untuk mewakili keseluruhan proses dekomposisi yang telah dilakukan. Hal ini berdasarkan dari nilai masing-masing komponen sehingga dapat digunakan pada tahap grouping.

\section{Tahap rekonstruksi}

Pada tahap rekonstruksi, terdapat dua langkah

yang digunakan untuk mendapatkan komponen trend, komponen seasonality, dan komponen noise dari eigentriple yang dihasilkan pada tahap dekomposisi, yaitu grouping dan diagonal averaging.

\section{Grouping}

- Pengelompokan Komponen Noise 


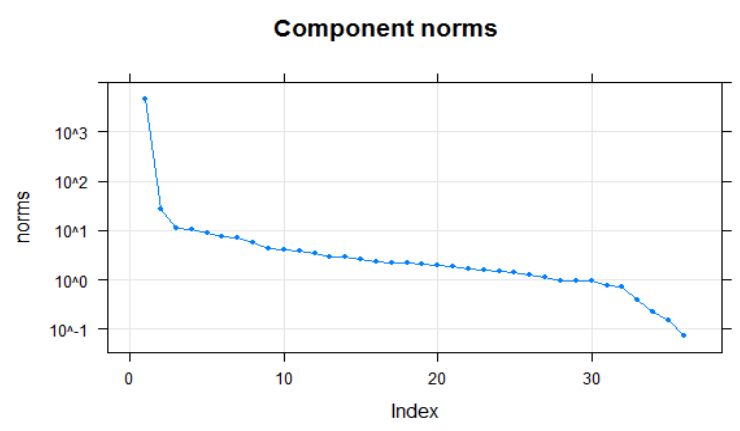

Gambar 4.2 Plot dari 35 Nilai Singular Pada Gambar 4.2, dapat dilihat bahwa nilai singular $l_{1}=67.9736413$ merupakan nilai terbesar yang berarti nilai singular dari $l_{1}$ memberikan pengaruh terbesar dari komponen deret waktu terhadap karakteristik data dibandingkan dengan yang lainnya. Hal ini dapat juga diartikan bahwa pengaruh komponen pertama sangat besar pada pembentukan rekonstruksi sinyal. Nilai singular selanjutnya cukup jauh berbeda dengan yang pertama dan cendereung menurun. Dari penurunan ini dapat diketahui dua hal yaitu komponen periodeik dan noise. Pada Gambar 4.2, diketahui bahwa nilai singular mulai menurun secara lambat pada eigentriple 32 sampai eigentriple 36 sehingga eigentriple 32 sampai eigentriple 36 diidentifikasi sebagai komponen noise. Dengan demikian nilai parameter effect grouping ( $r$ ) adalah $r=32$ karena jumlah eigentriple yang tidak mencerminkan noise pada plot dari nilai singular adalah 32 . Meskipun eigentriple yang mencerminkan noise sudah diidentifikasi, namun ada kemungkinan jumlah eigentriple yang mencerminkan noise bisa bertambah. Sisa eigentriple yang tidak berkaitan dengan trend dan seasonality dari 32 eigentriple pertama akan dikelompokkan ke dalam kelompok noise.

- Pengelompokan Komponen Trend dan Seasonality

Setelah mendapatkan komponen noise, langkah selanjutnya adalah melakukan pengelompokan terhadap eigentriple yang berkaitan dengan trend dan seasonality. Jumlah eigentripleyang digunakan untuk yang digunakan untuk mengidentifikasi komponen trend dan komponen seasonality adalah 36 eigentriple. 36 eigentriple yang digunakan untuk mengidentifikasi komponen trend dan komponen seasonality terdiri dari eigentriple 1, eigentriple 2, eigentriple 3 , ...,eigentriple 36. Plot dari deret yang direkonstruksi dapat digunakan untuk mengidentifikasi eigentriple yang berkaitan dengan trend dan seasonality.

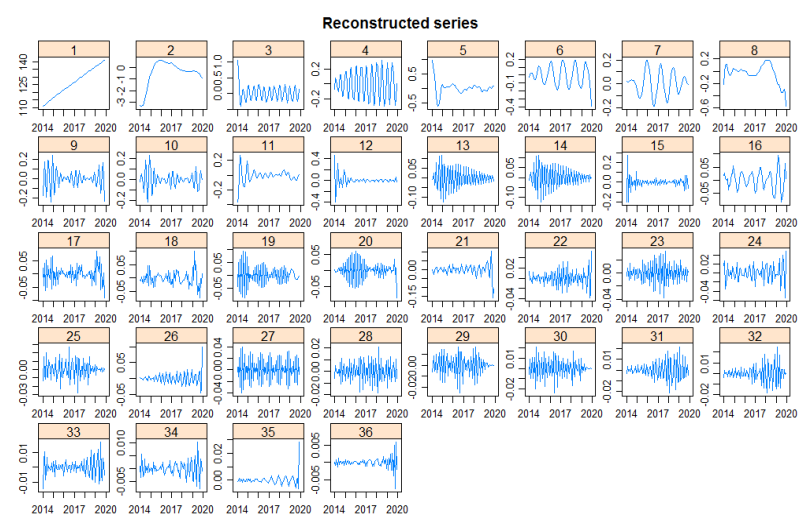

Gambar 4.3 Plot dari Deret yang direkonstru-

ksi (Grafik Eigenvector)

Pada Gambar 4.3 setiap nilai eigenvector di atas terlihat bahwa setiap eigenvector membentuk pola-pola tertentu. Hal ini memperlihatkan bahwa data Indeks Harga Konsumen di Sulawesi Selatan dari Januari 2014 sampai Desember 2019 melibatkan beberapa komponen aditif trend dan seasonality.

\section{Diagonal Averaging}

Pada langkah terakhir dalam tahap rekonstruksi yaitu diagonal averaging, masing-masing komponen dapat direkonstruksi dengan menggunakan masing-masing eigentriple yang terkait.

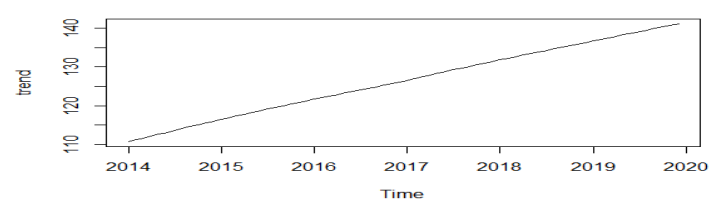

Gambar 4.4 Trend yang direkonstruksi Gambar 4.4 merupakan hasil dari komponen trend yang direkonstruksi oleh eigentriple $1 .$.

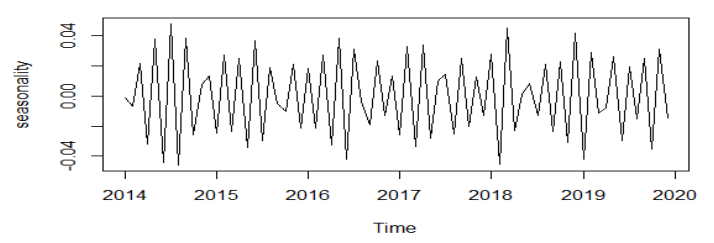


Gambar 4.5 Seasonality yang Direkonstruksi

Gambar 4.5 menampilkan hasil dari komponen seasonality yang direkonstruksi oleh eigentriple 27 dan eigentriple 28.

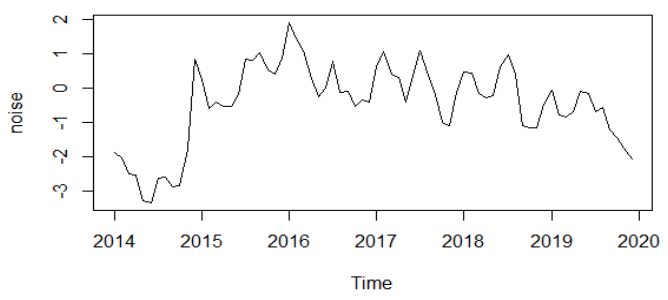

Gambar 4.6 Noise yang Direkonstruksi Gambar 4.6 menampilkan hasil dari komponen noise yang direkonstruksi oleh eigentriple 32 , eigentriple $33, \ldots$, eigentriple 36.

TAHAP PERAMALAN

Tabel 4.6 Hasil Peramalan Bulan Januari 2019 sampai Desember 2019

\begin{tabular}{lcr}
\hline & $\begin{array}{l}\text { Data } \\
\text { Aktual }\end{array}$ & $\begin{array}{l}\text { Data } \\
\text { Ramalan }\end{array}$ \\
\hline Januari 2019 & 136.61 & 137.37 \\
Februari 2019 & 136.36 & 137.84 \\
Maret 2019 & 136.65 & 138.30 \\
April 2019 & 137.23 & 138.76 \\
Mei 2019 & 138.28 & 139.22 \\
Juni 2019 & 138.56 & 139.68 \\
Juli 2019 & 138.50 & 140.14 \\
Agustus 2019 & 138.99 & 140.60 \\
September 2019 & 138.78 & 141.07 \\
Oktober 2019 & 138.88 & 141.53 \\
November 2019 & 139.03 & 141.99 \\
Desember 2019 & 139.08 & 142.45 \\
\hline
\end{tabular}

Plot data hasil peramalan IHK bulan Januari 2019 sampai Desember 2019 disajikan dalam gambar 4.7 sebagai berikut.

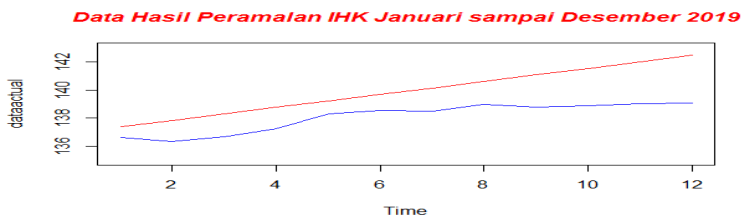

Gambar 4.7 Plot data hasil peramalan IHK bulan Januari sampai Desember 2019

Gambar 4.7 menampilkan plot data hasil peramalan IHK bulan Januari 2019 sampai Desember 2019 yang terus meningkat pada setiap bulan.

\section{AKURASI PERAMALAN}

Berdasarkan nilai MAPE yang diperoleh pada tahapan akurasi peramalan didapatkan nilai MAPE sebesar $1,32 \%$ yang artinya kurang dari 10\%, maka dapat disimpulkan bahwa metode peramalan dengan menggunakan metode Singular Spectrum Analysis (SSA) dengan window length sudah sangat baik untuk meramalkan Indeks Harga Konsumen di Sulawesi Selatan Januari Tahun 2014 sampai Desember Tahun 2019.

Tabel 4.7 Data Hasil Peramalan Januari sampai Desember 2020

\begin{tabular}{lc}
\hline & Data Hasil Ramalan \\
\hline Jan 2020 & 141,92 \\
Feb 2020 & 142,37 \\
Mar 2020 & 142,82 \\
Apr 2020 & 143,27 \\
Mei 2020 & 143,72 \\
Jun 2020 & 144,17 \\
Jul 2020 & 144,62 \\
Ags 2020 & 145,07 \\
Sept 2020 & 145,52 \\
Okt 2020 & 145,97 \\
Nov 2020 & 146,42 \\
Des 2020 & 146,88 \\
\hline
\end{tabular}

Dari Tabel 4.7 dapat dilihat data hasil peramalan bulan Januari 2020 dengan angka IHK sebesar 141,92 dan terus meningkat sampai bulan Desember 2020 dengan angka IHK sebesar 146,88.

\section{KESIMPULAN}

Hasil peramalan Indeks Harga Konsumen di Sulawesi Selatan bulan Januari 2020 sampai Desember 2020 menggunakan metode Singular Spectrum Analysis (SSA) diperoleh nilai Indeks Harga Konsumen (IHK) mengalami peningkatan. Nilai indeks harga konsumen tertinggi terjadi pada bulan Desember 2020 sebesar 146,88 dan nilai Indeks Harga Konsumen (IHK) terendah terjadi pada bulan Januari 2020 sebesar 141,92.Akurasi hasil peramalan Indeks Harga Konsumen (IHK) di Sulawesi Selatan pada Bulan Januari 2020 sampai Desember 2020 diperoleh nilai MAPE sebesar 1,32\%. Nilai MAPE yang diperoleh kurang dari 10\% sehingga dapat disimpulkan bahwa 
peramalan dengan menggunakan Singular Spectrum Analisis (SSA) sudah sangat baik untuk meramalkan data Indeks Harga Konsumen (IHK) di Sulawesi Selatan.

\section{DAFTAR PUSTAKA}

[1] Abraham, Bovas \& Johannes, Ledolter, 1983."Statistical Method for Forecasting"(New York:Jhon Wiley \& Sons. Inc.)

[2] Arif Pani Desvita \& Evi Desmita, 2015."Penerapan Metode Box-Jenkins dalam meramakan Indeks Harga Konsumenn di Kota Pekanbaru", (Pekanbaru:Jurnal Sains Matematika dan Statistika Vol.1 No. 1)

[3] Aswi dan Sukarna. 2006. "Analisis Deret Waktu: Teori dan Aplikasinya”.(Makassar:Andira

Publisher) [4] Badan Pusat Statistik Sulawesi Selatan. 2019."Perkembangan Indeks Harga Konsumen / Inflasi Sulawesi

Selatan".(Makassar:https://sulsel.bps.g o.id/)

[4] Badan Pusat Statistik Sulawesi Selatan,2019."Sulawesi Selatan dalam Angka (2015,2016,2017,2018)" (Makassar:https://sulsel.bps.go.id/)

[5] Debi Anggita Sasti, 2017. "Metode Pemulusan Eksponensial Holt-Winters untuk Peramalan Data Deret Waktu Musiman"(Universitas Lampung: Fakultas Matematika dan Ilmu Pengetahuan Alam)

[6] Fadhilah, Nurul \& Gumgum, 2017. "Metode SSA pada Data Produksi Perikanan Tangkap di Provinsi Jawa Barat'(Bandung:Universitas Padjadjaran Bandung)

[7] Golyandina, N., Nekrutkin, V., dan Zhigljavsky, A.,.2001."Analysis of Time Series Structure: SSA and Related Technique"(London: Chapman \& Hall)

[8] Gunawan Adi Saputro \& Marwan Asri, 2000.

Perusahaan",(Yogyakarta:BPFE)

[9] Hassani, Hossein \& Zigljavsky, A. 2007. "Singular Spectrum Analysis: Methodology and Aplication to
Economic

Data"(Springer

Science+Bussines Media,LLC)

[10]Hirlan Khaeri, Eko Yulian \& Gumgum Darmawan, 2007. "Penerapan Metode Singular Aanalysis (SSA) pada Peramalan Jumlah Penumpang Kerete Api di Indonesia Tahun 2017'(Bandung:UNPAD)

[11] Khan \& Poskitt, 2011. "Moment Test for Window Length Selection in Singular Spectrum Analysis"(Australia:Monash University)

[12]Leeuw \& Crucher, 2009. "Singular Spectrum Analysis in $R$ "(Los Angeles:Departement of Statistics, University of California)

[13]Lubis, Johra, \& Gumgum, 2017. "Peramalan Indeks Harga Konsumen (IHK) dengan Metode Singular Spectral Analysis (SSA) dan Seasonal Autoregressive Integrated Moving Average(SARIMA)"(Bandung:Universit as Padjadjaran)

[14]Myung, No Kang. 2009. "Singular Spectrum Analysis"(California:Thesis University of California)

[15] Untung Sus Andriyanti, \& Adul Basith, 1999. "Metode dan Aplikasi Peramalan", (Jakarta:Erlangga, 1999)

[16] William w.s. wei,2006. "Time Series Analysis (Univariate Methods)", Addison Wesley Publishing Company 